\title{
OFWS IN FOREIGN CINEMA: AN INTRODUCTION
}

\author{
Joel David \\ Inha University
}

Certain transformations presented themselves in the process of developing this special section. A draft of the paper I had provided for the first Kritika Kultura Global Classroom Lecture appeared to overlap with the journal's call for papers on globalization and diasporic identity. I knew of two other colleagues working on similar material, and both of them expressed interest in responding to the CFP. None of us could expand our individual material to monograph length, however, so we toyed with the idea of creating a singular co-authored text.

Unfortunately upon exchanging our ideas with one another, we concluded that the resulting studies would be too cumbersome to force into a singular, ideally elegant presentation. When the editors encouraged us to finalize our individual papers anyway, with the intent of reading the three as texts that address the issue of the imaging of Overseas Filipina Workers [note please the gender-specific designation, as well as the articles' appreciation of migrant wives as people who labor in the private sphere] in foreign films, we were taken aback by an element that had taken hold of - possessed, if you will - the writing.

In my case, it came from an instinctive urge to re-read Jacques Derrida's Specters of Marx, and led from there (as it did the others) to Bliss Cua Lim's engagement with Derrida and his illustrious predecessors in Translating Time. The manner in which the three articles configured the OFW as a spectral presence, feminized and feminine, haunting the circuits of a globalized postnational system might prove too irresistible to scholars eager to announce the arrival, if not triumph, of postmodernity in Philippine life and culture.

Yet divergent as the texts are, nothing in the articles suggests that this way of looking deserves to be upheld and applauded, if only for its novelty value. The first one, "Phantom in Paradise," claims that an OFW-in-foreign cinema Urtext had been lurking all this time, hiding in plain sight in a major but overlooked Hollywood production, John Huston's adaptation of Carson McCullers's Reflections in a Golden Eye, in the person of a biologically male "maid" brought to a US military camp by the couple who employed him. The second article, Taeyun Yu's "Reincarnation of 
the Pinay Subaltern," posits that the special category of Otherness described by Gayatri Spivak may be utilized in inspecting two East Asian films (also adaptations of novels) featuring Filipinas working out their relationships with Korean men: a Japayuki in Yangil Choi's All Under the Moon and a migrant wife in Han Lee's Wandeugi. The third article, Patrick Campos's "Ghostly Allegories," dwells intently on original film fictions that proceed from abusive treatments of the alwaysvulnerable diasporic body; in Kelvin Tong's Singaporean film The Maid, the ghost of a slain worker reaches out to her successor, while in Yam Laranas's The Echo, a murdered wife's spirit haunts the vicinity where she had been killed, seeking justice for the violence visited on her.

Beyond the increasingly literal spectrality of the central characters discussed in the papers' narrative, we can also note how the film productions inscribe an openended circularity: from a Hollywood-initiated project (Reflections in a Golden Eye) where the "Pinay" attains a subversive centrality via the book author's and filmmaker's appreciation of Otherness, through East Asian productions (All Under the Moon and Wandeugi) where the artists acknowledge the presence of OFWs as a vital element of their cultures' everyday experience, to films where the OFWs suffer the worst possible fate - getting killed on the job, as it were - that typically awaits them, with one production (The Maid) still East Asian but the other one (The Echo) this time American again, but with Filipino talents exercising total creative control.

Beyond these admittedly reductive observations, the individual papers must be granted their space to present and develop their respective arguments. I speak as much for the other authors as myself in acknowledging the pleasures as well as the difficulties in grappling with such complex, urgent, and transmutable phenomena, and we look forward to the further generation of images and discourses on the subject. 


\section{Works Cited}

Derrida, Jacques. Specters of Marx: The State of the Debt, the Work of Mourning, E the New International. Trans. Peggy Kamuf. New York: Routledge, 1994. Print.

Lim, Bliss Cua. Translating Time: Cinema, the Fantastic, and Temporal Critique. Quezon City: Ateneo de Manila UP, 2011. Print.

McCullers, Carson. Reflections in a Golden Eye. Boston: Houghton Mifflin, 1941. Print. Spivak, Gayatri C. "Can the Subaltern Speak?" 1988. Colonial Discourse and PostColonial Theory: A Reader. Eds. Patrick Williams and Laura Chrisman. New York: Columbia UP, 1994. 66-111. Print. 